\title{
Then there were four
}

\section{Washington}

THE long war over the fate of the 'Silver Spring' monkeys entered a new phase last week when three of the remaining seven monkeys kept at the Delta Regional Primate Research Center in Louisiana were killed after a series of experiments were carried out on their brain activity. As in the past, neither side in the fight over the fate of the monkeys was willing to soften their rhetoric. Both the animal rights groups and the congressmen who regard the monkeys as symbols of laboratory mistreatment of animals, and their opponents in the research community and the National Institutes of Health (NIH) continued to denounce each other's motives.

The office of Congressman Robert Roe, which tried unsuccesfully to have experiments delayed until this week in order for Roe to discuss the monkey's fate with William Raub, the acting head of $\mathrm{NIH}$, was scathing in its criticisms. Gregory Simon, staff director in Roe's office, described NIH's decision to kill the monkeys as "a vulgar display of muscle", which appeared to be designed "merely to make the point that the scientific community is totally in control of animal research and will not let anybody else influence the way it is done". Roe's office threatened public hearings on NIH's conduct and renewed efforts to pass a bill that would force NIH to send the remaining monkeys to an animal sanctuary.

People for the Ethical Treatment of Animals (PETA), the animal rights group which has made the monkeys into a public issue, erected a protest sculpture, depicting the 'torture' of a monkey on a laboratory apparatus, outside the Department of Health and Human Services. PETA reminded the press that the monkeys are still the biggest cause of public appeals to the White House, claiming that it had received 45,000 letters last month asking Barbara Bush, the wife of the president, to free them.

But NIH continues to point out that it has acted correctly and according to the demands of the law. Raub said that it had sought permission to kill the three animals after their health deteriorated and veterinary experts had recommended euthanasia. "The department has made its intentions known for a long period," says Raub, "once the court matters were cleared up it was our obligation to proceed. A delay for an arbitrary period of time would be totally contrary to the representation we made to the court, Congress and everyone else."

Animal rights groups and $\mathrm{NIH}$ have agreed on virtually nothing from the start fo the Silver Spring saga. According to PETA, when police recovered 17 of the crab-eating macaques from the Silver Spring laboratory of Edward Taub in 1981, they found evidence that the animals had been mistreated. Taub, they claim, was later convicted of cruelty to animals in a Maryland court. Supporters of Taub disagree, pointing out that Taub was cleared of all charges on appeal and further exonerated in independent investigations.

The latest twist in the saga came after the Physicians Committee for Responsible Medicine, another animal welfare group, failed after a long period of court action to obtain an order to block the euthanasia of three of the monkeys.

Alex Pacheco, spokesman for PETA, says that for "NIH to paint this as a mercy killing is just another lie". He believes that the monkeys were used in experiments and then killed so that NIH could justify having refused for years to release the animals to a sanctuary. PETA claims that the experiments are bogus and points out that in 1985, Raub, who was then Deputy Director of Extramural Research at NIH, wrote that "we have no research protocols, ongoing or planned, for which these animals are appropriate".

Raub says that "it has been explained many times over that the letter was a response to a very narrow proposal". Since then times have changed and the monkeys have emerged as an extraordinarily valuable resource, not for the experiments on rehabilitation from injury which were originally planned, but to test new hypotheses concerning the degree to which the brain is able to reorganize itself after inputs to specific regions are lost. The Silver Spring monkeys had had nerves cut in their forearms.

Experiments conducted on the three monkeys before they were killed revealed "massive reorganization" in the cortex, according to Timothy Pons of the National Institute of Mental Health who lead the team. The data seem to confirm those gained from experiments carried out on one of the monkeys which was killed earlier this year (see Nature 343, 581; 15 February 1990). With data from four monkeys in hand, Pons says he will prepare a scientific paper for publication.

The significance of the science is not really the problem bothering Roe, who is chairman of the House of Representatives Committee on Science, Space and Technology, so much as the way in which the sensitive issue of the monkeys has been handled. Roe's staff members have spent the last six months, according to Simon, "working with PETA and with NIH to come up with the middle ground - an independent panel that would review the disposition of the monkeys". When agreement had apparently been reached, Simon claims that NIH changed its mind. "Once they won in court everything changed and we're talking strictly 'might is right", says Simon.

But Raub says that it was incorrect to say that NIH backed out of the negotiation. He said he had found it very "disheartening how little progress we made and how far apart the views of the animal rights groups and the NIH were. As we were making little progress there and the court restraints were being resolved a hundred per cent in our favour, and these animals had been judged by experts as candidates for euthanasia as far back as 1988, our obligation under the Animal Welfare Act was that we had to proceed with [the euthanasia] of those three animals". Alun Anderson AUSTRALIAN SPACEPORT

\section{Soviet rockets gain US go ahead \\ Washington}

Prospects for the Australian Space Base at Cape York in northern Queensland are once more looking bright after US President George Bush indicated last week that he would not prevent US commercial satellites from being launched on Soviet-built rockets.

A major problem for the base has been that its likely customers were US companies wanting to launch US-made satellites while its cheapest source of launch vehicles lay in the Soviet Union. Until last week, the United States had objected to Soviet launches for US satellites, partly because they feared 'unfair' competition for domestic launches from state-subsidized Soviet organizations and partly because they feared that sensitive satellite technology might get into the hands of Soviet technicians.

The Cape York base, which will lie conveniently close to the equator, will cost around $\mathrm{A} \$ 350$ million to build and could be ready for its first launches in 1995 . The project is entirely commercial and is backed by a large Australian property developer, but the contract for running the base seems likely to go to a US company or to British Aerospace. It is not yet certain that the spaceport will be built, as environmental impact studies have yet to be completed and objections from aboriginal groups considered (see Nature 343, 400; 1 February 1990).

Tougher competition for satellite launches is bound to follow the entry of Soviet vehicles into the field, alongside Arianespace which is already well established, and the several US companies that are just beginning to provide commercial launches. A controversial US decision made last year also gave limited rights to the Chinese to launch US satellites.

Alun Anderson 